Available online at http://journal.stkip-andi-matappa.ac.id/index.php/histogram/index

Histogram : Jurnal Pendidikan Matematika ., 2019, 199 - 209

\title{
PEMBELAJARAN INQUIRI BASED LEARNING PADA MATERI LIMAS SMP NEGERI 16 BANDA ACEH
}

\author{
Muhamad Saleh $^{1}$, Ernisa $^{2}$, Aklimawati ${ }^{3}$, Rifaatul Mahmuzah ${ }^{4}$ \\ 1,2,3,4 Universitas Serambi Mekah \\ * Corresponding Author. Email: msalehginting@gmail.com
}

Received: 25 Juli 2019; Revised: 18 Agustus 2019; Accepted: 30 September 2019

\begin{abstract}
ABSTRAK
Materi matematika didominasi oleh hal-hal yang bersifat abstrak. Sementara tingkat berfikir siswa pada usia anak Sekolah Menengah Pertama masih banyak kendala mengenai berfikir abstrak. Untuk itu perlu diupayakan proses pembelajaran Limas disesuaikan dengan taraf berfikir siswa. Tujuan Penelitian ini adalah (1) untuk mengetahui hasil belajar siswa melalui penerapan Inquiri Based Learning (IBL) dan (2) respon siswa terhadap penerapannya. Pendekatan yang digunakan adalah kuantitatif. Populasi dalam penelitian ini adalah seluruh siswa kelas VIII SMP Negeri 16 Banda Aceh terdiri dari empat rombongan belajar. Sampel sebanyak dua kelas yang dipilih secara random. Instrumen penelitian yang digunakan yaitu: tes dan non tes (angket). Hasil penelitian menunjukkan bahwa nilai rata-rata siswa di kelas eksperimen lebih baik dibandingkan siswa dikelas kontrol. Siswa di kelas eksperimen mendapatkan nilai rata-rata 78.66, sedangkan di kelas kontrol 68.57. Berdasarkan uji statistik menggunakan SPSS Ver 21 diperoleh bahwa Nilai sign $(0,003)$ kurang dari 0,05 sehingga dapat disimpulkan bahwa hasil belajar kelas eksperimen lebih baik daripada kelas kontrol. Respon yang diberikan siswa terhadap kegiatan belajar mengajar pada pembelajaran IBL secara keseluruhan adalah positif dan termasuk dalam kriteria respon sangat baik dengan rata-rata persentase respon siswa sebesar 97,4\%.

Kata Kunci: IBL, luas, volume, limas.

How to Cite: Saleh, M., Ernisa., Aklimawati., \& Mahmuzah, R. (2019). Pembelajaran Inquiri Based Learning pada Materi Limas SMP Negeri 16 Banda Aceh. Histogram: Jurnal Pendidikan Matematika, 3(2), 199-209, doi: http://dx.doi.org/10.31100/histogram.v3i2.405 Permalink/DOI: http://dx.doi.org/10.31100/histogram.v3i2.405
\end{abstract}

\section{PENDAHULUAN}

Matematika merupakan ilmu dasar perkembangan teknologi modern yang mempunyai peranan penting dalam berbagai disiplin ilmu dan memajukan daya pikir manusia. Selain itu, matematika juga dapat dijadikan suatu alat pikir untuk memecahkan masalah dalam berbagai persoalan matematika. Oleh karena itu, matematika dapat digunakan sebagai sarana untuk memecahkan masalah dalam kehidupan sehari-hari (Herdian, 2009; Nurharini, D., \& Wahyuni, 2008; Uno, H, 2007).

Sebagian besar siswa masih mengalami kesulitan dan tidak mampu menemukan pemecahan dalam berbagai masalah yang diajukan kepada mereka. Kesulitan yang dialami oleh siswa disebabkan oleh beberapa factor, termasuk kualitas dan kemampuan siswa ketika belajar matematika di sekolah dasar. Lebih lanjut (Saleh, M., Prahmana, R, C, I., Isa, 


\section{Histogram: Jurnal Pendidikan Matematika, 3 (2), 2019 - 200 Muhamad Saleh, Ernisa, Aklimawati, Rifaatul Mahmuzah}

M., 2018) mengatakan "The learning model emphasizing algorithms, without giving enough time and chance to find the knowledge, it will be meaningless for students".

Pada materi bangun ruang limas, siswa kesulitan menemukan rumus luas permukaan dan volume limas serta sulit menyelesaikan masalah yang berkaitan dalam kehidupan sehari-hari serta tidak memahami konsep rumus, perhitungan dan cara menganalisa soal cerita dalam kehidupan sehari-hari (Sunarsi, 2009). Dalam hal ini dibutuhkan "intervensinya" sehingga lingkungan belajar difasilitasi untuk membantu siswa menjalani proses menemukan sendiri pengetahuan yang mereka cari.

Bruner dalam (Trianto, 2012) menyebutkan bahwa pembelajaran IBL merupakan suatu model pembelajaran yang lebih menekankan pentingnya pemahaman tentang struktur materi dari suatu ilmu yang dipelajari, perlunya belajar aktif sebagai dasar dari pemahaman sebenarnya, dan nilai dari berfikir secara induktif dalam belajar. Oleh karena itu, model pembelajaran IBL ini tepat untuk diterapkan dalam pembelajaran matematika materi luas permukaan dan volume limas.

Melalui pendekatan pembelajaran IBL, proses pembelajaran dilaksanakan dengan melakukan penekanan pada keaktifan siswa dalam belajar, siswa terlebih dahulu mengamati permasalahan yang diberikan guru kepada siswa melalui proses orientasi, merumuskan masalah, merumuskan hipotesis, mengumpulkan data, menguji hipotesis, dan menarik kesimpulan. Dengan cara ini siswa diharapkan dapat lebih mudah memahami konsep-konsep matematika khususnya pada konsep luas permukaan dan volume limas.

Berikut ini adalah salah satu jawaban dari soal hasil penelitian yang dilakukan (Sumadiasa, 2014):

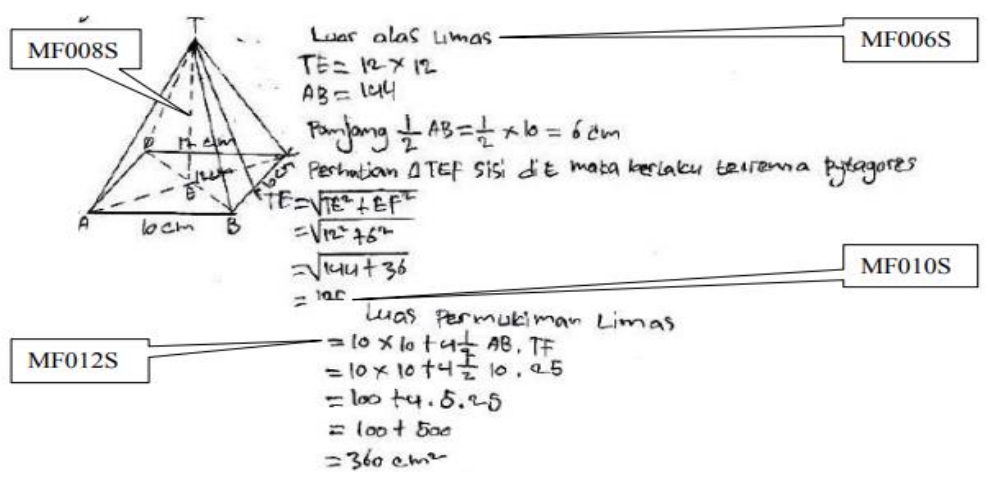

Gambar 1: Kesalahan siswa dalam menyelesaikan soal luas permukaan limas

Berdasarkan jawaban soal di atas, didapat dua jenis kesalahan yang dilakukan siswa yaitu kesalahan konseptual dan kesalahan prosedural. Kesalahan konseptual terdiri dari: (1) kesalahan konsep yaitu siswa salah dalam menghitung luas alas limas yang 


\section{Histogram: Jurnal Pendidikan Matematika, 3 (2), 2019 - 201 \\ Muhamad Saleh, Ernisa, Aklimawati, Rifaatul Mahmuzah}

disebabkan karena siswa salah mensubstitusi angka-angka yang diketahui dari soal ke dalam rumus. Siswa menggunakan tinggi limas yaitu $12 \mathrm{~cm}$ untuk menghitung luas alas limas, sedangkan panjang sisi alas limas yang sebenarnya adalah $10 \mathrm{~cm}$ (MF006S). Siswa menganggap tinggi sisi tegak limas sebagai tinggi limas (MF008S), dan (2) siswa salah dalam melakukan operasi hitung penjumlahan, yaitu $144+36=175$, sedangkan hasil penjumlahan sebenarnya adalah 180 (MF010S). Kesalahan prosedural yang dilakukan oleh siswa terdiri dari: (1) siswa tidak menuliskan yang diketahui dan ditanyakan dari soal (MF004S), (2) kesalahan strategi yang dilakukan yaitu siswa tidak menuliskan rumus luas permukaan limas (MF012S), dan (3) siswa tidak memberikan kesimpulan akhir dari jawaban yang diperolehnya (MF014S).

Pembelajaran merupakan suatu proses yang kompleks dan melibatkan berbagai aspek yang saling berkaitan (Ifadloh, V, N., Santoso, N, B., \& Supardi, K, 2012). Pembelajaran berasal dari kata ajar yang berarti petunjuk yang diberikan kepada orang supaya diketahui atau dituruti, sedangkan pembelajaran berarti proses, cara, perbuatan menjadikan orang atau makhluk hidup belajar. Pada hakikatnya belajar dan pembelajaran adalah suatu kegiatan yang tidak dapat terpisahkan dari kehidupan manusia, dengan belajar manusia dapat mengembangkan potensi-potensi yang dimilikinya (Hamalik, 2008; Thobroni, M., \& Mustofa, 2012).

Berdasarkan pengertian pembelajaran di atas dapat disimpulkan bahwa pembelajaran adalah suatu kegiatan yang dilakukan oleh guru dengan bahan ajar yang telah dipersiapkan dan dilaksanakan dengan menarik. Dengan demikian siswa memperoleh berbagai pengalaman khususnya di bidang tertentu dengan standar isi yang telah ditetapkan sehingga timbul perubahan dalam pengetahuan, pemahaman, keterampilan. Selain itu, perubahan pada nilai sikap dalam diri siswa terhadap ilmu matematika yang erat kaitannya dalam dunia nyata.

Pembelajaran matematika merupakan suatu bentuk untuk mempelajari yang menggunakan bahasa simbol dan membutuhkan penalaran serta pemikiran yang logik dalam pembuktiannya. Hal ini sejalan dengan pendapat (Suherman, 2003) bahwa "Matematika terbentuk sebagai hasil pemikiran manusia yang berhubungan dengan ide, proses, dan penalaran".

Dalam belajar matematika pengalaman belajar yang lalu memegang peranan penting dalam memahami konsep-konsep yang baru. Oleh karena itu, dalam mempelajari matematika haruslah bertahap dan berurutan serta sesuai dengan pelajaran yang lalu. Hal yang paling utama dalam mempelajari matematika adalah pemahaman pengetahuan 


\section{Histogram: Jurnal Pendidikan Matematika, 3 (2), 2019 - 202 Muhamad Saleh, Ernisa, Aklimawati, Rifaatul Mahmuzah}

tentang konsep. Dilanjutkan dengan pengetahuan tentang prosedur dan pengetahuan tentang bagaimana mengaitkan konsep dan prosedur dalam menyelesaikan masalah matematika.

"Model pembelajaran adalah suatu pola yang digunakan sebagai pedoman dalam perencanaan pembelajaran di kelas atau pembelajaran dalam tutorial dan untuk menentukan perangkat-perangkat pembelajaran termasuk didalamnya buku-buku, film, komputer, kurikulum" (Uno, H, 2011). Model pembelajaran adalah kerangka konseptual yang melukiskan prosedur yang sistematis dalam mengorganisasikan pengalaman belajar untuk mencapai tujuan tertentu dan berfungsi sebagai pedoman bagi para perancang pembelajaran dan para pengajar dalam merencanakan aktivitas belajar-mengajar. Penggunaan model pembelajaran harus disesuaikan dengan materi pembelajaran yang diajarkan kepada siswa. Hal ini dikarenakan tidak semua model pembelajaran tepat diterapkan pada proses pembelajaran. Oleh karena itu, guru harus menyesuaikan antara materi dan model pembelajaran yang digunakan (Trianto, 2009).

$I B L$ berarti suatu rangkaian kegiatan belajar yang melibatkan secara maksimal seluruh kemampuan siswa untuk mencari dan menyelidiki secara sistematis, kritis, logis, analitis, sehingga mereka dapat merumuskan sendiri penemuannya dengan penuh percaya diri. Pembelajaran $I B L$ merupakan suatu model pembelajaran yang lebih menekankan pentingnya pemahaman tentang struktur materi dari suatu ilmu yang dipelajari, perlunya belajar aktif sebagai dasar dari pemahaman sebenarnya, dan nilai dari berfikir secara induktif dalam belajar (Sumiati \& Arsa, 2009; Trianto, 2012). Model IBL merupakan proses pembelajaran dibangun atas pertanyaan-pertanyaan yang diajukan siswa, sehingga para siswa didorong untuk memecahkan masalah, dan bukan sekedar menerima instruksi langsung dari gurunya. Tugas guru dalam lingkungan belajar bebasis pertanyaan ini bukanlah untuk menyediakan pengetahuan, namun membantu siswa menjalani proses menemukan sendiri pengetahuan yang mereka cari dan guru berfungsi sebagai fasilitator dan bukan sumber jawaban.

Menurut (Wijaya, 2010) Inquiri Based Learning didasari atas pemikiran Jhon Dewey, seorang pakar pendidikan Amerika, yang mengatakan bahwa pembelajaran, perkembangan, dan pertumbuhan seorang manusia akan optimal saat mereka dikonfrontasikan dengan masalah nyata dan substantif untuk dipecahkan. Ia percaya bahwa kurikulum dan instruksi seharusnya didasarkan pada tugas dan aktivitas berbasis komunitas yang integratif dan melibatkan para pembelajar dalam tindakan-tindakan sosial pragmatis yang membawa manfaat nyata pada dunia. 


\section{Histogram: Jurnal Pendidikan Matematika, 3 (2), 2019 - 203 \\ Muhamad Saleh, Ernisa, Aklimawati, Rifaatul Mahmuzah}

Kata Inquiry berasal dari Bahasa Inggris yang berarti mengadakan penyelidikan, menanyakan keterangan, melakukan pemeriksaan (Echols, J. M., \& Shadily, 2005). (Kusmaryono, H., \& Setiawati, 2013), pendekatan inquiry based learning adalah suatu pendekatan yang digunakan dan mengacu pada suatu cara untuk mempertanyakan, mencari pengetahuan (informasi) atau mempelajari suatu gejala.

Model pembelajaran IBL adalah suatu model yang menuntut siswa untuk lebih aktif dalam mengajukan pertanyaan-pertanyaan, mencari informasi, dan melakukan penyelidikan untuk menemukan sendiri suatu konsep. Dalam hal ini guru membimbing siswa melakukan kegiatan dengan memberi pertanyaan awal dan mengarahkannya pada suatu kegiatan diskusi. IBL memberikan pengalaman-pengalaman belajar yang nyata dan aktif bagi siswa. Siswa belajar menjadi seorang ilmuwan dimana mereka diberi kesempatan untuk menyelidiki dan mencari jawaban sendiri.

Rumusan masalah dalam penelitian ini terbagi dua, yaitu: 1) berhubungan dengan pertanyaan "apakah hasil belajar siswa melalui penerapan IBL lebih baik dari siswa yang diajarkan dengan konvensional pada materi luas permukaan dan volume limas, serta 2) bagaimana respon siswa terhadap penerapan model pembelajaran IBL?

\section{METODE PENELITIAN}

Pendekatan yang digunakan dalam penelitian ini berupa pendekatan kuantitatif, Menurut (Moleong, 2005) "penelitian kuantitatif mencakup setiap jenis penelitian yang didasarkan atas persentase, rata-rata, chi kuadrat, dan perhitungan statistik lainnya”.

Jenis penelitian yang digunakan dalam penelitian ini adalah penelitian eksperimen. Penelitian eksperimen yang digunakan adalah true eksperimental design yaitu adanya dua kelompok dalam penelitian, kelompok pertama diberi perlakuan disebut kelompok eksperimen sedangkan kelompok kedua tidak diberi perlakuan yang disebut kelompok kontrol (Sugiyono, 2013). Dalam penelitian ini penelitian eksperimen dilakukan dengan menerapkan model pembelajaran IBL di kelas eksperimen dan model konvensional di kelas kontrol.

\section{A. Populasi dan Sampel Penelitian}

(Arikunto, 2006) menyatakan bahwa "Populasi adalah keseluruhan objek yang diteliti, sedangkan sampel adalah sebagian atau wakil yang diteliti”. Pengambilan sampel merupakan suatu hal yang penting untuk diperhatikan, karena penelitian bertujuan untuk mengambil kesimpulan terhadap populasi dari sampel tersebut. Populasi dalam penelitian ini adalah seluruh siswa kelas VIII SMP Negeri 16 Banda Aceh berjumlah 78 orang. 


\section{Histogram: Jurnal Pendidikan Matematika, 3 (2), 2019 - 204 Muhamad Saleh, Ernisa, Aklimawati, Rifaatul Mahmuzah}

Adapun sampel dalam penelitian ini sebanyak dua kelas yaitu kelas VIII-3 dan kelas VIII4 yang terdiri dari 40 orang, dengan teknik pengambilan sampel dilakukan secara random.

\section{B. Instrumen Penelitian}

Instrumen penelitian merupakan salah satu perangkat yang digunakan dalam mencari sebuah jawaban pada suatu penelitian. Adapun yang menjadi instrumen dalam penelitian ini adalah berbentuk tes dan non tes: (1) Tes Awal (Pre-Test), soal diberikan berbentuk essay yang berjumlah tujuh butir soal memuat materi persegi panjang, segi tiga, kubus, dan phytagoras. Tes Ini bertujuan untuk mengetahui kemampuan awal siswa sebelum proses belajar mengajar dimulai; (2) Tes Akhir (Post-Test), diberikan kepada kedua kelas (eksperimen dan control) bertujuan untuk mengetahui kemampuan atau pengetahuan siswa setelah diterapkan model IBL pada materi Luas Permukaan Limas dan Volume Limas berbentuk essay; (3) Angket berisi tentang respon siswa terhadap model pembelajaran IBL yang telah diterapkan. Angket terdiri dari sepuluh pertanyaan dengan setiap pertanyaan terdapat alternatif jawaban "setuju" atau "tidak setuju". Angket ini akan diberikan pada pertemuan terakhir sebelum jam pelajaran berakhir. Penilaian hasil angket respon siswa menggunakan rumus berikut:

$$
\text { Kriteria Repon Siswa }=\frac{\text { jumlah total }}{\text { jumlah skor seluruh item }} \times 100 \%
$$

Berdasarkan rumus di atas, maka didapatkan skala penilaian interpretasi nilai respon siswa dengan menetapkan besar persentase dengan kriteria sebagai berikut:

Tabel 1. Kriteria dan Persentase Respon Siswa

\begin{tabular}{clc}
\hline No & \multicolumn{1}{c}{ Kriteria } & Interval \\
\hline 1 & Sangat Baik & $84 \%-100 \%$ \\
\hline 2 & Baik & $68 \%-83 \%$ \\
\hline 3 & Cukup Baik & $52 \%-67 \%$ \\
\hline 4 & Kurang Baik & $36 \%-51 \%$ \\
\hline 5 & Tidak Baik & $20 \%-35 \%$ \\
\hline
\end{tabular}

(Sumber: Farola, Tahun: 2013)

Kegiatan/proses belajar menggunakaan pendekatan IBL dengan tahapan sebagai berikut:

1. Guru membagi tugas kepada siswa meneliti suatu masalah dikelas.

2. Siswa dibagi menjadi beberapa kelompok, masing-masing kelompok mendapat tugas tertentu yang harus dikerjakan.

3. Siswa menelaah dan membahas tugas kelompok.

4. Siswa membuat laporan yang tersusun dengan baik.

5. Melaporkan kerja kelompok disidang pleno (diskusi secara luas). 


\section{Histogram: Jurnal Pendidikan Matematika, 3 (2), 2019 - 205 Muhamad Saleh, Ernisa, Aklimawati, Rifaatul Mahmuzah}

6. Merumuskan kesimpulan

(Eggen, P., \& Kauchak, 2007; Suprijono, 2012; Wenning, 2011).

\section{Teknik Analisis Data}

Tahapan analisis data menggunakan SPSS versi 21 adalah dengan melakukan uji statistika non parametrik pada pengujian hipotesis yaitu Uji Mann Whitney U.

Pernyataan hipotesis penelitian adalah "hasil belajar siswa yang diajarkan dengan menerapkan model IBL lebih baik dibandingkan dengan siswa yang diajarkan dengan menerapkan pembelajaran konvensional pada materi luas permukaan dan volume limas di SMP Negeri 16 Banda Aceh dengan kriteria pengujian hipotesis yang akan dilakukan, pada taraf signifikan $\alpha=0,005$ dan derajat kebebasan $(\mathrm{dk}=\mathrm{n}-2)$.

\section{HASIL DAN PEMBAHASAN}

Tabel 2. Rerata Pretest dan Posttest Hasil Belajar

\begin{tabular}{ccc}
\hline \multirow{2}{*}{ Kelas } & \multicolumn{2}{c}{ Rerata data } \\
\cline { 2 - 3 } & Pre-test & Post-test \\
\hline Eksperimen & 62,95 & 78,66 \\
\hline Kontrol & 67,26 & 68,57 \\
\hline
\end{tabular}

(Sumber: Data Primer, Tahun: 2018)

Tes diberikan kepada siswa dan dikerjakan secara individual. Berdasarkan pre test yang telah diberikan diperoleh rata-rata kelas eksperimen 62,95 dan kelas kontrol 67,26. dan berdasarkan uji yang dilakukan diperoleh bahwa sampel kemampuan awal tidak berbeda secara signifikan

Tabel 3. Uji Kesamaan Rerata Pretest Kelas Kontrol dan Kelas Eksperimen

\begin{tabular}{ll}
\hline & Gabungan Pretest \\
\hline Mann-Whitney U & 155,000 \\
\hline Wilcoxon W & 386,000 \\
\hline $\mathrm{Z}$ & $-1,230$ \\
\hline Asymp. Sig. (2-tailed) & 0,219 \\
\hline Exact Sig. [2*(1-tailed Sig.)] & 0,236 \\
\hline
\end{tabular}

(Sumber: Data Primer, Tahun: 2018)

Nilai sig lebih dari 0.05 sehingga dapat disimpulkan bahwa tidak terdapat perbedaan hasil belajar pada pretest pada kedua kelas (eksperimen dan kontrol).

Pada hasil posttes diperoleh masing-masing kelas terrdapat peningkatan, namun kelas eksperimen terjadi peningkatan yang sangat signifikan dibanding dengan peningkatan rerata pada kelas kontrol. 


\section{Histogram: Jurnal Pendidikan Matematika, 3 (2), 2019 - 206 Muhamad Saleh, Ernisa, Aklimawati, Rifaatul Mahmuzah}

Tabel 4. Uji Kesamaan Rerata Posttest Kelas Kontrol dan Kelas Eksperimen

\begin{tabular}{ll}
\hline & Gabungan Posttest \\
\hline Mann-Whitney U & 92,000 \\
\hline Wilcoxon W & 282,000 \\
\hline$Z$ & $-2,941$ \\
\hline Asymp. Sig. (2-tailed) & 0,003 \\
\hline Exact Sig. [2*(1-tailed Sig.)] & 0,003 \\
\hline \multicolumn{2}{l}{ (Sumber: Data Primer, Tahun: 2018$)$}
\end{tabular}

Nilai sign kurang dari 0,05 sehingga dapat disimpulkan bahwa hasil belajar kelas eksperimen lebih baik daripada kelas kontrol.

Berdasarkan hasil pre-test (materi, ragam kesalahan yang dilakukan oleh siswa termasuk pada kesalahan prosedural dan konseptual. persegi panjang, segitiga, kubus, perkalian, dan phytagoras). Kesalahan yang dilakukan tersebut yaitu kesalahan konseptual dan kesalahan penerapan prosedural.

Tabel 5. Contoh kesalahan yang dilakukan oleh siswa

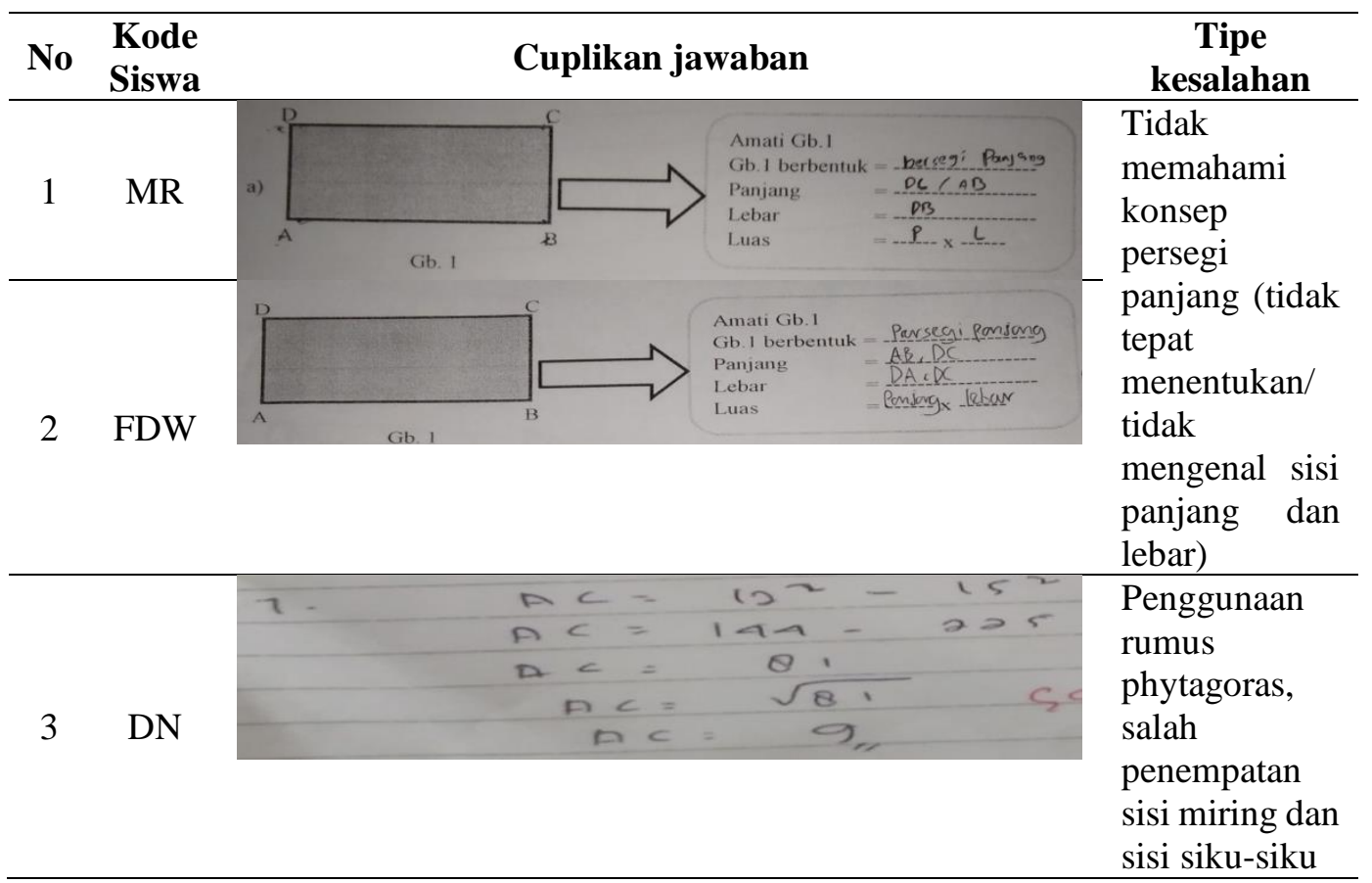

(Sumber: Data Primer, Tahun: 2018)

Berdasarkan hasil pre-test di atas, siswa melakukan kesalahan koseptual dan kesalahan prosedural. Hal ini sejalan dengan pendapat (Hudojo, 2009) bahwa jenis-jenis kesalahan yang dilakukan siswa dalam menyelesaikan soal matematika, yaitu kesalahan konseptual dan kesalahan prosedural. Kesalahan konseptual yang dilakukan berupa kesalahan konsep, fakta, dan prinsip sedangkan kesalahan prosedural yang dilakukan 


\section{Histogram: Jurnal Pendidikan Matematika, 3 (2), 2019 - 207 \\ Muhamad Saleh, Ernisa, Aklimawati, Rifaatul Mahmuzah}

berupa siswa tidak mencermati perintah soal. Salah satu solusi yang dilakukan yaitu meminta siswa yang menjawab soal dengan benar untuk mengerjakan soal bersama-sama di papan tulis serta menjelaskan kembali kepada teman-temannya yang belum memahami soal-soal yang terdapat pada soal pre-tes tersebut. Dengan demikian, siswa jauh lebih memahami dasar-dasar materi luas permukaan limas dan volume limas sebelum diterapkan.

Respon siswa dalam penelitian ini merupakan tanggapan siswa melalui angket setelah mengikuti pembelajaran. Respon siswa terhadap model pembelajaran IBL diperoleh dengan jumlah skor seluruh item respon siswa 820 dan jumlah total respon siswa 799. Hasil respon siswa dengan menggunakan skala likert yaitu jumlah total 799 dan jumlah skor seluruh item 820 .

$$
\begin{aligned}
\text { Kriteria Repon Siswa } & =\frac{\text { jumlah total }}{\text { jumlah skor seluruh item }} \times 100 \% \\
& =\frac{799}{820} \times 100 \% \\
& =97,4 \%
\end{aligned}
$$

Dari hasil respon di atas dapat disimpulkan bahwa respon yang diberikan terhadap kegiatan belajar mengajar pada pertemuan pertama sampai pertemuan ke empat dengan menggunakan model IBL secara keseluruhan 97,4\% dimana siswa tertarik dan termotivasi mengikuti kegiatan belajar mengajar selanjutnya. Selain itu, respon siswa dapat dilihat dari persentase dan kriteria yang ditetapkan oleh (Farola, 2013) dimana secara keseluruhan siswa memberikan respon sangat baik terhadap pelaksanaan pembelajaran IBL pada pokok bahasan luas permukaan dan volume limas di SMP Negeri 16 Banda Aceh.

Dalam pembelajaran penggunaan model pembelajaran IBL, siswa memahami materi yang diajarkan dengan caranya sendiri, yaitu siswa mengembangkan sendiri materi yang telah didapatkan sebelumnya. Hal ini sejalan dengan (Echols, J. M., \& Shadily, 2005) mengatakan bahwa pendekatan IBL merupakan suatu pendekatan digunakan dan mengacu pada suatu cara untuk mempertanyakan, mencari pengetahuan (informasi), atau mempelajari suatu gejala.

\section{KESIMPULAN DAN SARAN}

\section{A. Kesimpulan}

Berdasarkan hasil penelitian yang telah dilakukan, dapat diambil beberapa kesimpulan sebagai berikut: (1) Penggunaan model pembelajaran IBL pada materi luas permukaan limas dan volume limas terhadap siswa kelas VIII SMP Negeri 16 Banda Aceh lebih baik dari pada model pembelajaran konvensional; (2) Siswa lebih mudah memahami 


\section{Histogram: Jurnal Pendidikan Matematika, 3 (2), 2019 - 208 Muhamad Saleh, Ernisa, Aklimawati, Rifaatul Mahmuzah}

dan menemukan hal-hal penting dalam materi pelajaran yang diberikan, dengan melakukan diskusi bersama dan kompetensi antar kelompok sehingga nilai yang diperoleh oleh siswa lebih meningkat dari sebelum penggunaan model pembelajaran tersebut; (3) Respon yang diberikan siswa terhadap kegiatan belajar mengajar pada pembelajaran IBL pada konsep luas permukaan dan volume limas bersifat aktif dan senang untuk mengikuti kegiatan belajar mengajar selanjutnya yaitu sebesar $97,4 \%$. Dengan demikian, pembelajaran $I B L$ merupakan salah satu model pembelajaran yang dapat mendorong siswa untuk ikut aktif dalam belajar.

\section{B. Saran}

Berdasarkan kesimpulan yang diperoleh dalam penelitian ini, maka peneliti menyarankan : (1) Bagi guru, hendaknya model pembelajaran IBL ini dapat dijadikan salah satu alternatif keterampilan dalam mengajar terutama pembelajaran matematika untuk meningkatkan hasil belajar siswa pada materi luas dan volume limas; (2) Bagi sekolah, hendaknya model pembelajaran IBL dapat dijadikan bahan dan pertimbangan untuk menentukan kebijakan dalam rangka meningkatkan mutu dan kualitas pendidikan.

\section{DAFTAR PUSTAKA}

Arikunto, S. (2006). Prosedur Penelitian. Jakarta: Rineka Cipta.

Echols, J. M., \& Shadily, H. (2005). Kamus Inggris Indonesia: An English-Indonesian Dictionary. Jakarta: PT. Gramedia.

Eggen, P., \& Kauchak, D. (2007). Educational Psychology. Windows on Classrooms. Seventh Edition. New Jersey: Pearson Merril Precentice Hall.

Farola, F. (2013). Pengembangan Perangkat Pembelajaranmodel Inquiri Based Learning Pada Standar Kompetensi Melakukan Instalansi Sound System di SMK 2 Surabaya. Jurnal Pendidikan Teknik Elektro, 2(2), 837-843.

Hamalik, O. (2008). Kurikulum dan Pembelajaran. Jakarta: PT. Bumi Aksara.

Herdian. (2009). Model Pembelajaran NHT (Numbered Head Together). Retrieved January 5, 2012, from http://herdy07.wordpress.com/2009/04/22/model-pembelajarannhtnumbered-head-together/

Hudojo, H. (2009). Belajar Dan Mengajar Matematika. Malang: IKIP Malang.

Ifadloh, V, N., Santoso, N, B., \& Supardi, K, I. (2012). Metode Diskusi Dengan Pendekatan Science, Environment, Technology, Society Dan Media Question Card. Unnes Science Education Journal, 1(2), 119-125.

Kusmaryono, H., \& Setiawati, R. (2013). Penerapan Inquiry Based Learning Untuk Mengetahui Respon Belajar Siswa Pada Materi Konsep Dan Pengelolaan Koperasi. Jurnal Pendidikan Ekonomi Dan Dinamika Pendidikan, 8(2), 133-145.

Moleong, L. . (2005). Metodolagi Penelitian Kualitatif. Bandung: Rosda.

Nurharini, D., \& Wahyuni, T. (2008). Matematika Konsep dan Aplikasinya: untuk SMP/MTs Kelas VIII. Jakarta: Pusat Perbukuan Departemen Pendidikan Nasional.

Saleh, M., Prahmana, R, C, I., Isa, M., \& M. (2018). Improving The Reasoning Ability of 


\section{Histogram: Jurnal Pendidikan Matematika, 3 (2), 2019 - 209 Muhamad Saleh, Ernisa, Aklimawati, Rifaatul Mahmuzah}

Elementary School Student Through The Indonesian Realistic Mathematics Education. Journal On Mathematics Education, 9(1), 41-54.

Sugiyono. (2013). Metode Penelitian Pendidikan Kuantitatif, Kualitatif, dan R\&D. Bandung: Alfabeta.

Suherman, E. (2003). Strategi Pembelajaran Matematika Kontemporer. Bandung: PT. Remaja Rosda Karya.

Sumadiasa, I. . (2014). Analisis Kesalahan Siswa Kelas VII SMP Negeri 5 Dolo Dalam Menyelesaikan Soal Luas Permukaan dan Volume Limas. Jurnal Elektronik Pendidikan Matematika Tadulako, 1(2), 197-208.

Sumiati \& Arsa. (2009). Metode Pembelajaran. Bandung: CV. Wacana Prisma.

Sunarsi, A. (2009). Analisis Kesalahan dalam Menyelesaikan Soal pada Materi Luas Permukaan serta Volume Prisma dan Limas pada Siswa Kelas VIII Semester Genap SMP Negeri 2 Karanganyar Tahun Ajaran 2008/2009. Universitas Sebelas Maret.

Suprijono, A. (2012). Cooperative Learning. Yogyakarta: Pustaka Pelajar.

Thobroni, M., \& Mustofa, A. (2012). Belajar dan Pembelajaran. Yogyakarta: AR Ruzz Media.

Trianto. (2009). Pembelajaran Inovatif Berorientasi Konstruktivistik. Jakarta: Prestasi Publiser.

Trianto. (2012). Mendesain Model Pembelajaran Inovatif Progresif. Jakarta: Kencana.

Uno, H, B. (2007). Model Pembelajaran Menciptakan Proses Belajar Mengajar Yang Kreatif dan Efektif. Jakarta: PT. Bumi Aksara.

Uno, H, B. (2011). Model Pembelajaran Menciptakan Proses Belajar Mengajar Yang Kreatif dan Efektif. Jakarta: PT. Bumi Aksara.

Wenning, C. . (2011). The Level Inquiry Model of Science Teaching. Journal Physic Education, 6(2), 9-16.

Wijaya, H. (2010). Penerapan Metode Inquiry dalam Pembelajaran Matematika Untuk Meningkatkan Kemampuan Logika Berpikir Matematika Siswa SMA N 1 Muara Enim. Pascasarjana Universitas Sriwijaya. 